\title{
NEI LOCALITY AND HOST PLANT RECORDS FOR TWO SPECIES OF NASUTITERMES (ISOPTERA: TERMITIDAE)
}

This research note reports work on an investigation concerning the ecology, geographic distribution, host tree species, and the control of two species of arboreal termites: Nasutitermes costalis (Holmgren) and $N$. nigriceps (Haldeman) in Puerto Rico, and except for control, also in St. Croix, St. Thomas and St. John of the U.S. Virgin Islands.

As a partial result of these investigations, the authors obtained a number of new locality records for these species, as well as host tree species, for this area of the Caribbean.

The most recent data on locality records for termites of this area was published by Dr. Thomas E. Snyder ${ }^{1}$ who in 1956 listed these termites by species as well as by localities.

\section{PUERTO RICO}

Vieques Island: The most abundant species, Nasutiternes nigriceps, was recorded by Snyder on 27 different host tree species. $N$. costalis is now reported for the first time from the more humid parts of the Island, in the western and northwestern zones as well as on Monte Pirata, on the following host trees: Albizia lebbeck, Citharexylum fruticosum, Cocothrinax argentea, Cocos nucifera, Leucaena leucocephala ${ }^{2}$ Mangifera indica and Torrubia fragans.

Culebra Island: Parvitermes discolor is the only termite species listed by Snyder from this locality. The authors found Nasutitermes nigriceps on Bucida buceras, Torrubia fragrans, Elaeodendron xylocarpum, Pisonia subcordata, Jacquinia arborea, Ficus citrifolia, Bursera simaruba, Laguncularia racemosa, Coccoloba uvifera, Cordia rickseckeri, Bourreria succulenta and Hippomane mancinella on this island.

Cayo Luis Peña, Culebra: This very small island, close to the western coast of Culebra, is now part of the U.S. Naval Reserve. Nasutitermes nigriceps was recorded there on Bucida buceras, Cephalocereus royenii, Torrubia fragrans, Pisonia subcordata, Coccoloba uvifera and Cordia glabra. This termite species is quite abundant on this small island where large nests

${ }^{2}$ Snyder, Thomas E., Termites of the West Indies, the Bahamas and Bermuda, J. Agr. Univ. P.R. 40(3): 189-202, 1956.

2 Botanical plant names employed herein are from Brother Alain Liogier's publications: "Nomenclatural changes and additions to Britton and Wilson's Flora of Porto Rico and the Virgin Islands", Rhodora 67, No. 772, 1965, and "Further changes and additions to the flora of Porto Rico and the Virgin Islands", Rhodora 69, No. 779, 1967 
were seen on the host trees. Both Cayo Luis Peña, as well as Culebra, were visited during June 5 to $7,1968$.

Isla Aves or Cayo Diablo: This small key forms a part of the so-called Cayo Icacos Complex which includes, in an easterly direction, the following keys: Aves, Lobos, Ratones and Icacos. In Isla Aves, Nasutitermes nigriceps was collected only from Capparis flexuosa. However, empty nests and tunnels were seen in a number of Coccoloba uvifera trees growing near the seashore. Isla Aves was visited on May 27, 1967.

Cayo Lobos: This rather small island was visited on September 7, 1966 and Nasutitermes nigriceps was recorded on the following trees: Coccoloba uvifera, Cocos nucifera and Ficus citrifolia.

Cayo Icacos: This is the largest island in the whole group and indeed difficult to survey because of spiny bushes and vines growing wild all over the place. Icacos was visited on August 10 and September 7, 1966. Nasutitermes nigriceps was found occurring on: Coccoloba uvifera, Pisonia subcordata, Conocarpus erecta, Canella winterana, Jacquinia arborea, Pithecellobium unguis-cati and Consolea rubescens.

Isla Ramos: This small island is very close to the port of Fajardo, on the east coast of Puerto Rico. The place was visited on July 16, 1966, and Nasutitermes nigriceps was found on Coccoloba uvifera, Cocos nucifera, Mangifera indica and Conocarpus erecta.

Isleta Marina or Cayo Obispo: This small but pretty island is still closer to the Fajardo port area and is used as a yacht basin. Nasutitermes nigriceps was collected here on Cocos nucifera and Coccoloba uvifera.

Isla Pineros: This small island is located right off the Roosevelt Roads Naval Base at Ceiba, quite close to the Puerto Rico Mainland and it thus has similar environmental conditions. Both $N$. nigriceps and $N$. costalis were recorded here from numerous tree species, the latter being more abundant.

\section{UNITED STATES VIRGIN ISLANDS}

St. Thomas: Nasutitermes nigriceps is the only species of arboreal termite recorded by Snyder from this locality. The authors had the opportunity to visit St. Thomas in April 1966 and in August 1969. N. nigriceps was recorded on 42 different host trees along the coast and hillsides, being the most common species in the lowlands. Nasutitermes costalis was found for the first time on the higher places of the Island, in the area near Mountain Top Hotel, attacking 15 different host tree species.

Water Island, St. Thomas: This small island is located off the most important harbor of St. Thomas, in Charlotte Amalie, capital of the island. Two visits were made to this locality, the first on August 18, 1969 by the authors of this paper, and the second by Martorell and Roy Woodbury, 
Plant Taxonomist at the Agricultural Experiment Station, on November 7 to $9,1969 . N$. nigriceps was found to occur here on Pisonia subcordata, Bucida buceras, Coccoloba uvifera, Trema lamarckiana, Torrubia fragans, Hippomane mancinella, Cassia macrantha, Ceiba pentandra, Elaeodendron xylocarpum, Thespesia populnae, Ficus citrifolia and Coccothrinax alta.

St. John: The island was visited August 15 to 17, 1969, where Nasutitermes nigriceps was found to occur on 51 different species of trees. This is the first report of arboreal termites from this locality. No other Nasutitermes species was found, although we searched both highest and most humid areas of the Island.

St. Croix: The species of Nasutitermes present in St. Croix have been already recorded by Snyder, namely: costalis, nigriceps and ephratae.

Luis F. Martorell José C. Garcia-Tudurí

Department of Entomology 